\title{
Market Feedback And Managers' Decisions In Private Placement - Evidence From Chinese Family Firms
}

Wanli Li, Xi'an Jiaotong University \& Shanghai University of International Business and Economics, China

Weiwei Gao, Xi'an Jiaotong University, China

Wei Sun, Xi'an Jiaotong University, China

\begin{abstract}
What effect does market feedback have on managers' decisions on private placement in family firms? Based on information asymmetry, agency theory, and corporate governance theory, we investigate the relationship between managers' final decisions and market feedback to the announcement. We find that managers in family firms accept market feedback in decision-making and their attitude can be affected by many external factors. Managers tend to listen to the market when family firms are non-high-tech, when family members participate in purchasing the placed shares, when family members serve as managers, and when separation of control rights from ownership is small.
\end{abstract}

Keywords: Family Firm; Private Placement; Agency Theory; Corporate Governance

\section{INTRODUCTION}

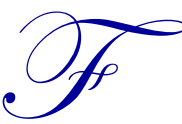
amily firms rely too much on internal funds to meet the business demand before. With the development of the business, external financing channels should be considered (Coleman \& Carsky, 1999). However, due to information asymmetry, small-to-medium enterprises have much difficulty in acquiring bank loans (Berger \& Udell, 2002; Chakraborty \& Hu, 2006; Uchida et al., 2012). In 2006, private placement was recognized as one way of refinancing in China for the issue of the Administrative Measures for Issuance of Securities by Listed Companies by the CSRC (China Securities Regulatory Commission). Since then, many Chinese companies, especially family firms, have refinanced through private placement in recent years due to its low requirement.

Table 1. Announcement and Implement of Private Placement

\begin{tabular}{|c|c|c|c|c|c|c|c|c|c|}
\hline & Final State & 2006 & 2007 & 2008 & 2009 & 2010 & 2011 & 2012 & Total \\
\hline \multirow{4}{*}{$\begin{array}{l}\text { Listed } \\
\text { companies }\end{array}$} & Total & 167 & 173 & 139 & 294 & 223 & 246 & 224 & 1466 \\
\hline & Competed & 90 & 107 & 83 & 197 & 133 & 136 & 119 & 865 \\
\hline & Adjusted & 51 & 49 & 42 & 65 & 56 & 69 & 80 & 412 \\
\hline & Cancelled & 26 & 17 & 14 & 32 & 34 & 41 & 25 & 189 \\
\hline \multirow{4}{*}{ Family firms } & Total & 53 & 63 & 43 & 86 & 113 & 111 & 108 & 577 \\
\hline & Completed & 32 & 42 & 27 & 59 & 70 & 64 & 59 & 353 \\
\hline & Adjusted & 13 & 15 & 11 & 17 & 25 & 28 & 35 & 144 \\
\hline & Cancelled & 8 & 6 & 5 & 10 & 18 & 19 & 14 & 80 \\
\hline
\end{tabular}

Note: We get the data from the website http://www.cninfo.com.cn/ where publish the information of private placement. One firm may have several private placements.

Table 1 is the announcement and implement of private placement from 2006 to 2012. It shows that the number of private placement has increased from 167 in 2006 to 224 in 2012. By 2012, there have been 1466 announcements in total, among which family firms account for nearly $40 \%$. Obviously, private placement has become an increasingly important way for companies, especially family firms, to refinance. However, among the announcements from family firms in 2006 , only $70 \%$ are completed as previously announced and $30 \%$ adjusted or cancelled, compared 
with the figures $65 \%$ and $35 \%$ in 2012 . Since family firms prefer private to public equity financing to maintain family control (Wu et al., 2007), what causes them not to implement the announced plans?

In many cases, managers will evaluate the effect on firm value before making decisions. They will not make announcements until they confirm that these decisions can bring a positive effect to the company. According to the efficient market hypothesis (EMH), capital market has a strong ability to process public information, which is superior to any individuals or institutions. If the market considers the company to neglect some important factors when making decisions, it will view the announcement as a negative signal and signal back to the company by trading down the stock price. Actually, in Luo's (2005) framework, managers are viewed to learn from the market if their M\&A decisions are affected by market reaction. Namely the market can not only redistribute wealth but also generate information to guide managers' decisions. So under this circumstance, should managers neglect market signal and complete the deal as previously determined, or accept market feedback and make some changes to the previous decision? In other words, is market feedback the main reason why family firms not implement the announced plans?

Family firms are often viewed as bearing exploitation of minority shareholders (Morck \& Yeung, 2003) and lacking professional management. However, some evidence shows that family firms outperform non-family firms multidimensionally (Anderson \& Reeb, 2003; Villalonga \& Amit, 2006), which results from its special ownership structure. Namely family shareholders act as stewards more than agents. The core of the debate between the former and the latter is that, what roles do managers in family firms play in decision-making process. What kind of influence does it bring to managers' behavior during private placement?

Focusing on the effect of market feedback on managers' final decisions, we analyze the private placement announced by Chinese family firms from 2006 to 2012 and examine the influence of firm characteristics. The findings contribute to two areas. First, different from previous studies that examine the role of market feedback in firms' investment decisions, we apply it into firms' financing decisions. Second, from the perspective of two-way information flow, we relate managers' decisions to market feedback and show that the market plays an important role in managers' decision-making.

The remainder is as follows. Section II reviews the literature. Section III develops the hypotheses. Section IV focuses on sample, data, and methodology. Section V presents the results. Section VI offers the results of robustness checks. Section VII concludes.

\section{LITERATURE REVIEW}

\section{Market Feedback and Managers' Decisions}

Luo (2005) defines the relationship between managers' decisions and market feedback as managers' learning. Kau et al. (2008) propose a different definition, which goes like: if the market reacts positively to the announcement and the deal is finally completed, or the market reacts negatively to the announcement and the deal is finally canceled, then managers learn from the market. No matter how learning is defined, the market has a significant effect on managers' decisions.

Studies on market feedback mainly concentrate on managers' investment decisions, especially on M\&A (Dye \& Sridhar, 2002; Kau et al., 2008; Aktas et al., 2011). Market has a strong ability in processing public information and can generate much new information after observing the announcement. It will feed the new information back to firms by impounding the information into stock prices. For example, the market will regard it as a bad signal in M\&A when acquirer's pricing is higher than target's market value. Acquirer's stock price will consequently fall. Extracting useful information, managers will then accept market feedback by adjusting the previously announced plan (Dye \& Sridhar, 2002). However, Blanchard et al. (1993) posit that market feedback may play a limited role in managers' decision-making due to some factors such as managers' self-interest. Managers may ignore market feedback due to their hubris (Roll, 1986). Aktas et al. (2009) also hold the same view that although the M\&A may bring negative effect to firm value, managers will still complete it as previously announced owing to their overconfidence. 
Jennings and Mazzeo (1991) argue that whether managers accept market feedback mainly depends on the amount of their private information, which is also examined by Luo (2005). In addition, Luo (2005) believes that managers tend to accept market feedback when the cost of canceling the initial decision is less, when information asymmetry is lower, or when the firm is smaller. From the perspective of corporate governance, Kau et al. (2008) conduct a study on M\&A, which shows that managers are more likely to cancel the announced decisions when the market reacts negatively to the announcement and are more likely to accept market feedback when their interests are more aligned with shareholders.

\section{Private Placement}

Because public offering can signal to the market that firm value is overestimated, it has a generally negative announcement effect (Asquith \& Mullins, 1986; Mikkelson \& Partch, 1986). However some other studies on IPO show that firm's initial returns depend on market demand, which plays an important role in its pricing (Mauer \& Senbet, 1992; Agarwal et al., 2008). Regardless of initial returns, stock price will go to balance which reflects firms' true value (Agarwal et al., 2008), indicating that the market not only has a super ability in information discovering and processing but also can make adjustment to previous prediction. Similarly, the market should also be able to make prediction and react to the announcement of private placement.

Kahneman and Tversky (1979) argue that investors tend to overweight firms' short-term performance at the expense of long-run performance. Thus abnormal returns around announcement day of private placement are very high while post-announcement stock price performance is greatly negative, indicating that the market can make some adjustments to the overestimated stock price and reacts timely to new emerging information (Hertzel et al., 2002; Tan et al., 2002). However, some scholars hold a different view that the market underreacts to the announcement of private placement (Chen et al., 2002). ${ }^{1}$

Some other studies on private placement conclude that private placement can be used by large shareholders to realize their self-interest. When they participate in purchasing shares, the discounts of the placement increase with the amount they purchase. It is consistent with the fact that large shareholders realize their control gains through private placement. Managers tend to sell stocks to passive investors to get loose supervision and achieve their aims to better control the firms by giving passive investors large discounts as compensation (Barclay et al., 2007).

Above all, we can see that the literature on private placement mainly focuses on its announcement effect, its longand short-term wealth effect, the stock price movement henceforth, and the discounts. Very few consider the effect of market feedback. As main decision-makers, managers can be affected by many external factors such as the supervision from boards and shareholders, the punishment when making wrong decisions, and the macro economic conditions. Therefore, the study on the relationship between managers' decisions and market feedback is very necessary.

\section{Managers in Family Firms: Agents or Stewards?}

The main conflict of early work on family business is whether managers in family firms act as agents or stewards. Agency problems arise when managers with superior private information exploit firm resources to maximize their personal gains, which stems from information asymmetry between the principle and the agent (Jensen \& Meckling, 1976). The conflict between owners and managers is substantially reduced with family involvement in both ownership and management (Fama \& Jensen, 1983). Due to significant shareholdings, family shareholders have incentive to supervise managers, thus reducing monitoring costs (Anderson \& Reeb, 2003) and improving the performance. However, agency problems may be more severe when there is little alignment between managers and the family or when managers can control the business with little ownership.

Actually, agency costs in family firms are mainly between the family and the minority shareholders (Morck \& Yeung, 2003). Generally speaking, the family has strong preference of control rights, which will probably make

\footnotetext{
${ }^{1}$ The difference in the view on the announcement effect of private placement results from the difference in countries' regulations. For example, in Singapore, shares cannot be sold to directors or substantial shareholders. But there are no special restrictions on this characteristic in China. 
private placement a tool for them to entrench other minority shareholders (Cronqvist \& Nilsson, 2005). They may destroy firm value by separating control rights from cash-flow rights using control-enhancing mechanisms (Villalonga \& Amit, 2006). On one hand, too much ownership with unchallenged control rights can induce owners' power abusing to exploit the business such as the extraordinary dividend payouts (DeAngelo \& DeAngelo, 2000). On the other hand, if the family aims to control the business with little ownership (also called pyramiding structure), other ways to exploit minority shareholders and gain control rights will emerge (Miller \& Le Breton-Miller, 2006). Both of them go against the maximization of firm value.

While the agency theory posits managers' self-interesting behavior, the stewardship theory indicates that regardless of ownership, managers in family firms will subordinate personal goals to business goals and tend to pursue nonfinancial goals (Corbetta \& Salvato, 2004). Actually, family owners often engage in emotional investment in the business (Bubolz, 2001). Consequently, managers in family firms often hold superior attitudes of stewardship (Miller \& Le Breton-Miller, 2006), which can improve the performance. However, the emotional ties don't blind the owners to impose agency cost control mechanisms on managers (Chrisman et al, 2007), suggesting that managers in family firms act as some kind of combination of agents and stewards.

\section{Literature Summary}

Studies on market feedback effect mainly focus on managers' investment decisions, with very few concerning the potential relationship between market feedback and financing decisions. Just as what we have mentioned above, managers also tend to utilize market feedback to improve financing decisions.

In the past, very limited attention was paid to small-to-median enterprises, especially family firms, in the studies on both market feedback and private placement. Actually, more and more Chinese family firms start to use private placement as a main channel to refinance in recent years. What's more, whether managers in family firms act as agents or stewards has been debated for years. It is valuable to investigate managers' behavior in Chinese family firms during private placement. In family firms' private placement, managers' attitude towards market feedback should be taken into account. Therefore, we discuss the relationship between market feedback and managers' final decisions in Chinese family firms' private placement and examine the factors of this relationship.

\section{HYPOTHESE DEVELOPMENT}

Previous studies argue that capital market can generate new information, which is not known to managers, and impound it into stock prices (Dye \& Sridhar, 2002). Some researchers examine that managers' final decisions can be affected by market reaction to the announcement in investment decision-making (Blanchard et al., 1993; Luo, 2005; Kau et al., 2008). Firms will adjust the announced repurchased amounts of shares based on the stock returns following the announcement (Stephens \& Weisbach, 1998). Managers' final decisions are influenced by market reaction to the registration of seasoned equity offering (Giammarino et al., 2004). Actually, not just the investment decisions, other corporate actions such as refinancing, can also be influenced by market feedback. Managers' behavior is reflected in their every decision (Luo, 2005).

Due to the highly concentrated ownership, family firms prefer private placement to public equity financing to maintain family control (Wu et al., 2007). Family involvement in management makes managers more prudent in making decisions. Compared with non-family firms, they may pay more attention to market feedback. What's more, their behavior can be affected by many external factors such as firms' industry, the supervision imposed on them, and the corporate governance mechanism. How do these factors work in managers' attitude towards market feedback in family firms?

First, market feedback to the announcement is less informative for high-tech firms than others. Compared with private placement, public offering requires firms to disclose more information, which can induce larger conveying costs. Furthermore, the disclosed information is easy to be used by competitors, which thus may be conducive to firms' development. Hence, high-tech family firms have the incentive not to disclose such information when it is disadvantageous to their competitiveness (Verrecchia, 1983; Wagenhofer, 1990). Therefore, family firms with abundant sensitive information prefer private placement (Hertzel \& Smith, 1993; Chemmanur \& Fulghieri, 1999). 
Consequently, the information asymmetry of private placement is higher for high-tech firms than others (Wu, 2004), although the disclosure of proprietary technology information is important for market to evaluate the project covered by the placement. Thus, family firms tend to reduce the disclosure of such critical information, resulting in the difficulty for outsiders to evaluate firm value. So high-tech firms have severe information opacity. Namely, family firms' industry can influence the information disclosure. Holding plenty of private information, managers in hightech family firms may regard market feedback less informative and tend to ignore it.

Second, according to the monitoring hypothesis, private placement can strengthen the supervision on managers. By introducing active large shareholders, private placement can increase ownership concentration, which can reduce agency problems and increase firm value (Wruck, 1989). Wu (2004) conducts a study on purchasers' properties and conclude that the placements with managers participating in purchasing have more discounts than those without managers, and the discounts increase with the decrease of managers' shareholding proportion. This evidence indicates that managers are self-interested. Hence, absence from monitoring managers can bring family firms much loss. Many studies show that the blockholders have greater incentive to oversight management. Therefore, family members participating in purchasing placed shares can restrain managers' self-interested behavior. Due to the supervision from family members, managers tend to adjust the previously announced plan according to market feedback in shareholders' best interests.

Third, managers' behavior can be affected not only by their nature but also by the kinship with leaders and the corporate governance mechanism (Chrisman et al., 2007). Whether managers in family firms act as stewards or agents has been debated for years. More closely aligned with firms, managers have more propensities to listen to the market (Kau et al., 2008), thus they act more as stewards. In China, most family firms are yet in their early stage. Many family members participate in both firms' daily management and the allocation of residual claims. That is, control rights are little separated from ownership. This mechanism narrows the information gap between controllers and managers. Under this circumstance, family managers act as stewards more than agents. Therefore, they have much motivation to run the business well. So they will notice market feedback and make proper decisions to improve firm value. To summarize:

H1: Managers in family firms are more likely to accept market feedback than those in non-family firms in private placement.

H2: Managers in family firms are less likely to accept market feedback in private placement when the firm is hightech.

H3: Managers in family firms are more likely to accept market feedback in private placement when family members participate in purchasing the placed shares.

H4: Managers in family firms are more likely to accept market feedback in private placement when family members serve as managers or when the separation of control rights from ownership is small.

\section{METHODOLOGY}

\section{Sample and Data}

We select announcement day of board resolution as pricing benchmark day. It is hand collected from the Report of Issuance of Private Placement announced on the website http//www.cninfo.com.cn. Other data are from CSMAR and WIND database. We define family firms as: if the business is ultimately controlled by one family or several connected families who together control at least $20 \%$ of the outstanding votes, it's a family firm (La Porta et al., 1999). Our initial sample includes 577 family firms during 2006 and 2012. The sample is then screened as follows: incomplete data, placements aiming at purchasing assets, financial firms, ST and *ST firms and placements without CSRC's approval are rejected. ${ }^{2}$ Finally, 459 family firms are identified. Ultimate ownership is measured with cash-

\footnotetext{
${ }^{2}$ The CSRC examines the plan according to the Detailed Rules for Implement of Non-public Issuance for Listed Companies. We focus on the influence of market feedback on managers' final decisions. So we exclude the data.
} 
flow rights while ultimate control rights with voting rights. Separation of control rights from ownership is measured with the difference between cash-flow rights and voting rights.

\section{Method}

Market feedback is measured with market reaction to the announcement. We use event study to examine market reaction and obtain $C A R$ (cumulative abnormal return) using market model:

$$
R i t=\alpha i+\beta i R M t+\varepsilon i t
$$

where Rit is firms' daily stock returns. $R M t$ is the daily returns of market portfolio. eit is the daily abnormal returns. We select $[-180,-30]$ days before announcement day as the estimation period. If stocks are suspended that day, the first trading day after the announcement is the benchmark day. [-5,5] days around announcement day are selected as the event window.

\section{Models and Variables}

Table 2. Definition Of Variables

\begin{tabular}{|c|c|}
\hline Variables & Definition \\
\hline Complete & It equals 1 if placement is completed as previously announced; otherwise it equals $0 .^{3}$ \\
\hline Accept & $\begin{array}{l}\text { It equals } 1 \text { if market reacts negatively and the firm gives up placing, or market reacts positively and the firm } \\
\text { completes the previously announced plan; otherwise it equals } 0 \text {. }\end{array}$ \\
\hline CAR & $\begin{array}{l}\text { Market reaction to the announcement. It is the cumulative abnormal return from }-5 \text { to } 5 \text { days around } \\
\text { announcement day. }\end{array}$ \\
\hline Family & It equals 1 if the firm is family firm; otherwise it equals 0. \\
\hline Tech & It equals 1 if the firm is high-tech; otherwise, it equals 0. \\
\hline Part & It equals 1 if family members participate in purchasing shares; otherwise it equals 0. \\
\hline Serve & It equals 1 if family members serve as CEOs or chairman of the board; otherwise it equals 0 . \\
\hline Wedge & Separation of control rights from ownership. \\
\hline Larown & Share proportions held by the largest shareholder. \\
\hline Famown & Share proportions held by the family. \\
\hline Market & It equals 1 if it is in "bull market" and equals 0 if it is in "bear market". 4 \\
\hline ROA & Firms' latest net margin before announcement day scaled by the assets. \\
\hline Level & The gearing from recent financial statements. \\
\hline Lnsize & Natural $\log$ of firm size. \\
\hline
\end{tabular}

We use the following Logit models to test the hypotheses:

$$
\begin{aligned}
& \text { Logit }(\text { Complete })=\beta+\alpha 1 \text { CAR }+\alpha 2 \text { Family }+\alpha 3 \text { CAR } \times \text { Family }+\alpha 4 Q 1 。 \\
& \text { Logit }(\text { Complete })=\beta+\alpha 1 \text { Tech }+\alpha 2 \text { CAR }+\alpha 3 \text { Part }+\alpha 4 \text { Serve }+\alpha 5 \text { Wedge }+\alpha 6 C A R \times \text { Tech }+\alpha 7 \text { CAR } \times \text { Part } \\
& \quad+\alpha 8 C A R \times \text { Serve }+\alpha 9 C A R \times \text { Wedge }+\alpha 10 Q 2 \\
& \text { Logit }(\text { Accept })=\beta+\alpha 1 \text { Tech }+\alpha 2 \text { Part }+\alpha 3 \text { Serve }+\alpha 4 \text { Wedge }+\alpha 5 Q 3
\end{aligned}
$$

Model 1 is to test the effect of family involvement on managers' attitude towards market feedback. Model 2 is the key model. Model 3 is for robustness checks. Definition of variables is in Table 2.

\footnotetext{
${ }^{3}$ Cases that the firm doesn't complete the announced plan include: it isn't implemented within one valid year such as prolonging validity period and issuing trans-right shares, the firms announce the failure or giving up implementing, and the firms announce the adjustment.

${ }^{4}$ Market is divided into "bull" and "bear" according to the trend of overall market direction during sustained period. For example, overall market direction kept increasing during June in 2005 and October in 2007, so it belongs to "bull" and overall market direction kept falling during November in 2007 and October in 2008, so it belongs to "bear".
} 


\section{RESULTS}

We investigate: (1) the relationship between market feedback and managers' final decisions on whether the previously announced plan is implemented. (2) The effect of family involvement on this relationship. (3) Whether the relationship varies with some factors. We winsorize the variables at $1 \%$ level.

\section{Relationship Between Market Feedback and Managers' Decisions}

Table 3. Relationship Between Market Feedback and Managers' Decisions

\begin{tabular}{lcc}
\hline \multicolumn{1}{c}{ Variables } & Test1 & Test2 \\
\hline Constant & $1.59^{*}(0.059)$ & $1.73 *(0.055)$ \\
\hline CAR & $1.28^{* * *}(0.000)$ & $0.85^{* *}(0.030)$ \\
\hline Family & & $-0.07(0.288)$ \\
\hline CAR $\times$ Family & & $1.21^{* *}(0.017)$ \\
\hline Market & $0.34 * * *(0.002)$ & $0.35^{* * *}(0.001)$ \\
\hline Larown & $0.002(0.284)$ & $0.002(0.295)$ \\
\hline ROA & $2.93 * *(0.028)$ & $2.98^{* *}(0.029)$ \\
\hline Lev & $0.55^{*}(0.081)$ & $0.54 *(0.085)$ \\
\hline Lnsize & $-0.09 * *(0.034)$ & $-0.10^{* *}(0.032)$ \\
\hline Industry & YES & YES \\
\hline Year & YES & YES \\
\hline Chi-Square & 31.09 & 31.08 \\
\hline Prob(chi-square) & 0.000 & 0.000 \\
\hline Nagelkerke R Square & 0.121 & 0.122 \\
\hline Note: $p<0.10, * *<0.05 * * *<0.01 . T h e$
\end{tabular}

Note: ${ }^{*} p<0.10,{ }^{* *} p<0.05,{ }^{* * *} p<0.01$. The italics are the $p$-values. The sample includes both family firms and non-family firms. CAR is the key variable in test 1 while $C A R$ and the interaction are the key variables in test 2 . We apply model 1 in the analysis.

It is widely accepted that family involvement in management makes family firms unique. What effect does it bring to managers' attitude towards market feedback? Table 3 displays the results addressing this question. We are interested in the coefficients of $C A R$ and the interaction. Coefficient of $C A R$ in test 1 is significantly positive, showing that market feedback plays an important role in managers' final decisions. After observing the announcement, market can generate some new information that guides managers. In test 2, coefficients of $C A R$ and the interaction are both significantly positive, showing that family involvement can make managers tend to listen to the market. ${ }^{5}$ Do the factors we mentioned above affect their attitude? We answer this question in the following sections.

${ }^{5}$ Li et al. (2015) argue that family involvement can reduce the probability of managers' acceptance about market feedback, different from our result. This may be attributed to the different classification of family firms. Literature has not reached a consensus on how to identify family firms. 


\section{Univariate Analysis}

Table 4. CARs Around Announcement Day

\begin{tabular}{|c|c|c|c|c|c|c|}
\hline \multirow{2}{*}{ Event period } & \multirow{2}{*}{$\begin{array}{c}\text { Full sample } \\
\mathrm{N}=459\end{array}$} & \multirow{2}{*}{$\begin{array}{c}\text { Completed } \\
\mathbf{N}=\mathbf{2 5 8}\end{array}$} & \multirow{2}{*}{$\begin{array}{c}\text { Adjusted } \\
\mathbf{N}=\mathbf{2 0 1}\end{array}$} & \multirow{2}{*}{\multicolumn{3}{|c|}{ Difference }} \\
\hline & & & & & & \\
\hline$(-10,10)$ & 0.066 & 0.079 & 0.050 & \multicolumn{3}{|c|}{$0.029 * *$} \\
\hline$(-5,5)$ & 0.057 & 0.078 & 0.029 & \multicolumn{3}{|c|}{$0.049 * * *$} \\
\hline$(-3,3)$ & 0.048 & 0.062 & 0.031 & \multicolumn{3}{|c|}{$0.031 * *$} \\
\hline \multicolumn{7}{|c|}{ Table 4-2: Whether Firm Is High-tech } \\
\hline & \multicolumn{3}{|c|}{ YES } & \multicolumn{3}{|c|}{ NO } \\
\hline \multirow{2}{*}{ Event period } & Completed & Adjusted & \multirow{2}{*}{ Difference } & Completed & Adjusted & \multirow{2}{*}{ Difference } \\
\hline & $\mathrm{N}=109$ & $\mathrm{~N}=95$ & & $\mathrm{~N}=149$ & $\mathrm{~N}=106$ & \\
\hline$(-10,10)$ & 0.038 & 0.078 & -0.040 & 0.125 & 0.027 & $0.098 * *$ \\
\hline$(-5,5)$ & 0.031 & 0.065 & -0.034 & 0.112 & -0.003 & $0.115 * * *$ \\
\hline$(-3,3)$ & 0.020 & 0.077 & -0.057 & 0.093 & -0.011 & $0.104 * * *$ \\
\hline \multicolumn{7}{|c|}{ Table 4-3. Whether Family Members Participate In Purchasing } \\
\hline & \multicolumn{3}{|c|}{ YES } & \multicolumn{3}{|c|}{ NO } \\
\hline \multirow{2}{*}{ Event period } & Completed & Adjusted & \multirow{2}{*}{ Difference } & Completed & Adjusted & \multirow{2}{*}{ Difference } \\
\hline & $\mathbf{N}=\mathbf{8 0}$ & $\mathbf{N}=63$ & & $\mathbf{N}=178$ & $\mathbf{N}=\mathbf{1 3 8}$ & \\
\hline$(-10,10)$ & 0.131 & 0.078 & $0.053 *$ & 0.054 & 0.041 & 0.013 \\
\hline$(-5,5)$ & 0.136 & 0.017 & $0.119 * * *$ & 0.052 & 0.035 & 0.017 \\
\hline$(-3,3)$ & 0.101 & 0.028 & $0.073 * *$ & 0.044 & 0.032 & 0.012 \\
\hline \multicolumn{2}{|c|}{ Table 4-4. Whether Family Members Serve As Managers } & \multicolumn{2}{|l|}{ YES } & \multicolumn{3}{|c|}{ NO } \\
\hline \multirow{2}{*}{ Event period } & Completed & Adjusted & \multirow{2}{*}{ Difference } & Completed & Adjusted & \multirow{2}{*}{ Difference } \\
\hline & $\mathbf{N}=193$ & $\mathbf{N}=122$ & & $\mathrm{~N}=65$ & $\mathbf{N}=79$ & \\
\hline$(-10,10)$ & 0.092 & 0.019 & $0.073 * *$ & 0.061 & 0.058 & 0.003 \\
\hline$(-5,5)$ & 0.084 & 0.011 & $0.073 * * *$ & 0.059 & 0.057 & 0.002 \\
\hline$(-3,3)$ & 0.070 & 0.013 & $0.057 * * *$ & 0.038 & 0.058 & -0.019 \\
\hline \multicolumn{7}{|c|}{ Table 4-5. Separation Of Control Rights From Ownership } \\
\hline & \multicolumn{3}{|c|}{ Large } & \multicolumn{3}{|c|}{ Small } \\
\hline & Completed & Adjusted & Difference & Completed & Adjusted & \\
\hline Event period & $\mathbf{N}=135$ & $\mathbf{N}=95$ & Dimerence & $\mathbf{N}=123$ & $\mathbf{N}=106$ & Dirterence \\
\hline$(-10,10)$ & 0.087 & 0.046 & 0.041 & 0.078 & 0.032 & $0.046^{* *}$ \\
\hline$(-5,5)$ & 0.083 & 0.040 & 0.043 & 0.072 & 0.020 & $0.052 * *$ \\
\hline$(-3,3)$ & 0.055 & 0.041 & 0.014 & 0.068 & 0.020 & $0.048 * *$ \\
\hline
\end{tabular}

Note: ${ }^{*} p<0.10, * * p<0.05, * * * p<0.01$. If firm's separation of two rights exceeds the median value, it is classified into sample with large separation; otherwise it is classified into sample with small separation.

Table 4 lists market reaction to the announcement. To eliminate the effect of measures, we measure market reaction with different event windows: $[-10,10],[-5,5]$, and $[-3,3]$. The difference in Table 4 is between $C A R$ s of the firms that complete the previously announced plan and those that finally cancel the announced plan.

Table 4-1 is the result of full sample. CARs are all bigger than zero, indicating that market reacts positively to the announcement, consistent with most of the studies on the announcement effect of private placement (Tan, 2002; Hertzel et al., 2002). Firms finally completing the placement have higher CARs than those that finally cancel the plan. Differences between them are all significant, showing that managers listen to the market during private placement: managers tend to complete the announced plan when market views them positively and cancel the plan when they are not admitted by market.

The results from Tables 4-2 to 4-5 show that, family firms that are non-high-tech, that with family members participating in purchasing, that with family members serving as managers, and that with small separation of two rights tend to accept market feedback. 


\section{Multivariate Analysis}

\section{Descriptive Analysis and Univariate Comparisons}

Table 5 reports the descriptive results of variables. Differences are between firms completing the placements and those that finally cancel the announced plans.

Table 5. Descriptive Statistics Of Variables

\begin{tabular}{l|c|c|cc}
\hline \multirow{2}{*}{ Variables } & Completed & Adjusted & \multirow{2}{*}{ Difference } & p-value \\
\cline { 2 - 5 } & $\mathbf{N}=\mathbf{2 5 8}$ & $\mathbf{N = 2 0 1}$ & $0.49 \%$ & 0.186 \\
\hline ROA & $3.29 \%$ & $2.80 \%$ & $-2.15 \%$ & 0.184 \\
\hline Level & $49.45 \%$ & $51.60 \%$ & $0.94 \%$ & 0.478 \\
\hline Famown & $35.04 \%$ & $34.10 \%$ & $0.16 *$ & 0.072 \\
\hline Lnsize & 21.34 & 21.18 & $0.61 *$ & 0.066 \\
\hline Wedge & 9.49 & 8.88 & $7.97 \% *$ & 0.089 \\
\hline Tech & $50.76 \%$ & $42.79 \%$ & $3.03 \%$ & 0.518 \\
\hline Market & $57.75 \%$ & $54.73 \%$ & $-2.94 \% * *$ & 0.012 \\
\hline Part & $29.00 \%$ & $31.84 \%$ & $-12.47 \% * * *$ & 0.004 \\
\hline Serve & $61.19 \%$ & $73.66 \%$ & & \\
\hline
\end{tabular}

Note: ${ }^{*} p<0.10,{ }^{* *} p<0.05, * * * p<0.01$. The italics are $p$-values.

Macro environment and information on shareholdings are both the information which can be directly acquired by the market. We thus control them in our models. However, Table 5 shows that ROA, Level, Famown, and Market all have no significant differences between firms completing the placements and those finally not. We also control the effect of firm size and the difference is significant, from which we draw the same conclusion to Luo's (2005). All the other variables have the expected results.

\section{Effect of Market Feedback On Managers' Decisions}

We apply model 2 into this analysis and Table 6 displays the results. In test $1, C A R$ is the key variable while in tests 2-6, CAR and the interactions are the key variables.

Table 6. Effect of Market Feedback On Managers' Decisions

\begin{tabular}{l|c|c|c|c|c|c}
\hline \multirow{2}{*}{ Variables } & Test 1 & Test2 & Test 3 & Test 4 & Test 5 & Test 6 \\
\hline \multirow{2}{*}{ Constant } & $4.06^{*}$ & $4.18^{* *}$ & $4.30^{* *}$ & $4.95^{* *}$ & $3.87^{*}$ & $4.57^{* *}$ \\
\hline \multirow{2}{*}{ Tech } & $(0.051)$ & $(0.047)$ & $(0.045)$ & $(0.026)$ & $(0.061)$ & $(0.036)$ \\
\hline \multirow{2}{*}{ CAR } & -0.19 & 0.03 & -0.19 & -0.23 & -0.19 & 0.06 \\
\hline \multirow{2}{*}{ Part } & $(0.163)$ & $(0.245)$ & $(0.173)$ & $(0.123)$ & $(0.164)$ & $(0.385)$ \\
\hline \multirow{2}{*}{ Serve } & $1.29^{* * *}$ & $3.51^{* * *}$ & $0.44^{* *}$ & $2.46^{* *}$ & $2.40^{* * *}$ & $1.65^{*}$ \\
\hline \multirow{2}{*}{ Wedge } & $(0.008)$ & $(0.001)$ & $(0.041)$ & $(0.030)$ & $(0.004)$ & $(0.085)$ \\
\hline \multirow{2}{*}{ CAR $\times$ Tech } & 0.01 & -0.02 & -0.10 & 0.03 & -0.01 & -0.14 \\
\hline \multirow{2}{*}{ CAR $\times$ Part } & $(0.435)$ & $(0.465)$ & $(0.325)$ & $(0.438)$ & $(0.434)$ & $(0.273)$ \\
\hline \multirow{2}{*}{ CAR $\times$ Serve } & $0.69^{* * *}$ & $0.65^{* * *}$ & $0.67^{* * *}$ & $0.45^{* *}$ & $0.70^{* * *}$ & $0.50^{* *}$ \\
\hline \multirow{2}{*}{ CAR $\times$ Wedge } & $(0.001)$ & $(0.002)$ & $(0.001)$ & $(0.024)$ & $(0.001)$ & $(0.016)$ \\
\hline \multirow{2}{*}{ Famown } & $0.02^{*}$ & $0.01^{*}$ & $0.02^{*}$ & $0.02^{*}$ & $0.02^{* *}$ & $0.02^{*}$ \\
\hline & $(0.085)$ & $(0.092)$ & $(0.091)$ & $(0.085)$ & $(0.049)$ & $(0.095)$ \\
\hline & & $-4.82^{* * *}$ & & & $-5.88^{* * *}$ \\
\hline & & $(0.001)$ & & & $(0.000)$ \\
\hline & & & $2.21^{* *}$ & & $(0.007)$ \\
\hline
\end{tabular}

(Table 6 continued on next page) 
(Table 6 continued)

\begin{tabular}{|c|c|c|c|c|c|c|}
\hline Variables & Test 1 & Test2 & Test 3 & Test 4 & Test 5 & Test 6 \\
\hline \multirow{2}{*}{ Market } & 0.18 & 0.22 & 0.16 & 0.18 & 0.20 & 0.21 \\
\hline & $(0.182)$ & $(0.142)$ & $(0.213)$ & $(0.185)$ & $(0.165)$ & $(0.157)$ \\
\hline \multirow{2}{*}{ ROA } & 0.30 & 1.04 & 0.55 & -0.56 & 0.52 & 1.59 \\
\hline & $(0.450)$ & $(0.348)$ & $(0.421)$ & $(0.419)$ & $(0.427)$ & $(0.277)$ \\
\hline \multirow{2}{*}{ Lev } & -0.52 & -0.13 & -0.48 & -0.72 & -0.53 & -0.13 \\
\hline & $(0.221)$ & $(0.421)$ & $(0.234)$ & $(0.143)$ & $(0.217)$ & $(0.428)$ \\
\hline \multirow{2}{*}{ Lnsize } & $-0.21 * *$ & $-0.23 * *$ & $-0.22 * *$ & $-0.24 * *$ & $-0.20 * *$ & $-0.25 * *$ \\
\hline & $(0.046)$ & $(0.032)$ & $(0.040)$ & $(0.033)$ & $(0.050)$ & $(0.025)$ \\
\hline$\chi^{2}$ & 24.71 & 27.56 & 27.33 & 29.85 & 27.67 & 39.18 \\
\hline $\operatorname{Prob}\left(\chi^{2}\right)$ & $(0.006)$ & $(0.004)$ & $(0.004)$ & $(0.002)$ & $(0.004)$ & $(0.000)$ \\
\hline Nagelkerke R2 & 0.142 & 0.167 & 0.147 & 0.158 & 0.146 & 0.197 \\
\hline
\end{tabular}

Test 1 in Table 6 is the result of managers' final decisions on market feedback. Coefficient of CAR is significantly positive, indicating that managers' final decisions are indeed affected by market feedback. The probability of completing the announced plans increases with market's favorability. Market plays an important role in managers' final decision-making.

In tests 2-5, we put each interaction into the model and test 6 includes all the interactions. Consistent with $H 2-H 4$, coefficients of the interactions $C A R \times T e c h, C A R \times P a r t, C A R \times$ Serve, and $C A R \times W e d g e$ are respectively significantly negative at $1 \%$ level, significantly positive at $5 \%$ level, significantly positive at $1 \%$ level, and significantly negative at $10 \%$ level. The results indicate that in final decision-making, managers tend to be affected by market feedback when family firm is non-high-tech, when managers are more strongly supervised, when managers are more aligned with firms, and when separation of control rights from ownership is smaller.

Family firms in high-tech industry have more inside information, which makes market less informative. Thus information asymmetry leads managers to tend to ignore the signal from market. Due to absence from daily management, the family may be blinded by managers. Participating in purchasing can offer them more occasions to observe managers' behavior. Namely, family involvement in private placement can make managers place firms' interest in the first, resulting in their tendency to accept market feedback. According to the stewardship theory, regardless of ownership, family managers (family members serve as managers) generally behave in firms' value maximization. That is, family managers will regard market feedback as guidance for their decisions in private placement. Furthermore, small separation of control rights from ownership can keep firms belonging to the family. Thus, the family possesses the incentive to monitor managers (Anderson \& Reeb, 2003), thereby increasing the probability that managers listen to the market.

In tests 1-6, coefficients of Serve and Wedge are both significantly positive. It may be related to the agency problems in Chinese family firms. In China, most of family firms are yet under control of founders. The imperfect corporate governance mechanism may lead the family to utilize their information superiority to exploit outsiders. (1) When family members sever as managers, as insiders, they have more private information. Under this condition, out of the intention to either meet fund demand or expropriate minority shareholders, managers may choose to complete the announced plan without considering other factors. (2) Large separation of control rights from ownership can induce severe agency problems. On one hand, pyramiding structure can amplify the financial and psychological gap between the firm and the family. In this case, private placement may be used by the family to expropriate minority shareholders. On the other hand, managers may use private placement to realize personal gains. Hence, when separation of the two rights is large and when family members serve as managers, firms are more likely to complete the previously announced plans.

Early work on family business mainly focuses on whether managers in family firms behave as agents or stewards (Chrisman et al., 2007). Results in Table 6 show that managers in family firms are some extent of combination of both. 


\section{ROBUSTNESS CHECKS}

We apply another method to examine managers' attitude towards market feedback beyond Luo's (2005) framework. According to Kau et al. (2008), if market favors the announced decision and it is finally completed, or market disfavors the decision and the plan is finally canceled, then managers accept market feedback. In Figure 1, managers listen to the market in area II and III.

Figure 1. Managers' Attitude Towards Market Feedback

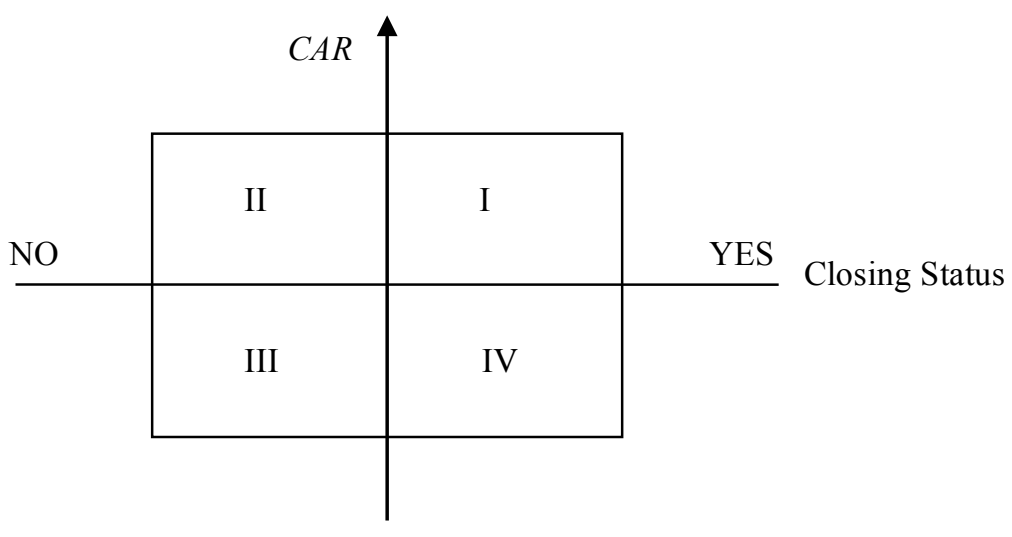

\section{Descriptive Statistics}

Table 7 reports the descriptive results. Table 7-1 show that there are 258 (56.21\%) firms completing the announced plan and 201 (43.79\%) firms finally cancel the plan. Table 7-2 reports the descriptive result of whether managers in family firms listen to the market. Result shows that most of managers in family firms accept market feedback. Table 7-3 is the joint result of Tables 7-1 and 7-2. No matter whether the announced plan is completed, most of managers in family firms make final decisions according to market reaction. It indicates that after the announcement, the market generates some new information not known to managers and guides them in decision-making.

Table 7. Private Placement And Managers' Attitude

\begin{tabular}{|c|c|c|c|c|}
\hline & Completed & \multicolumn{2}{|c|}{ Incomplete } & Total \\
\hline Number & 258 & \multicolumn{2}{|c|}{201} & 459 \\
\hline Percent & $56.21 \%$ & \multicolumn{2}{|c|}{$43.79 \%$} & $100 \%$ \\
\hline \multicolumn{5}{|c|}{ Table 7-2. Managers' Attitude Towards Market Feedback } \\
\hline & Accept & \multicolumn{2}{|c|}{ Not Accept } & Total \\
\hline Number & 267 & \multicolumn{2}{|c|}{192} & 459 \\
\hline Percent & $58.17 \%$ & & & $100 \%$ \\
\hline \multicolumn{5}{|l|}{ Table 7-3. Joint Results } \\
\hline & \multicolumn{2}{|c|}{ Completed } & \multicolumn{2}{|c|}{ Not Completed } \\
\hline & Number & Percent & Number & Percent \\
\hline Accept Market Feedback & 155 & $60.08 \%$ & 112 & $55.72 \%$ \\
\hline Not Accept Market Feedback & 103 & $39.92 \%$ & 89 & $44.28 \%$ \\
\hline
\end{tabular}

Note: We use $C A R(-5,5)$ to judge whether managers accept market feedback.

\section{Factors Affecting Managers' Attitude Towards Market Feedback}

Results of model 3 are presented in Table 8. Test 1 is the full sample result. In test 2, inspired by Kau et al. (2008), we use the subsample with $C A R<0$ only, for if market reaction to the announcement is highly positive $(C A R>>0)$, managers are not likely to cancel the decision, only if there are other key factors affecting them. Therefore, the subsample with $C A R<0$ is less noisy. 
Table 8. Results Of Robustness Checks

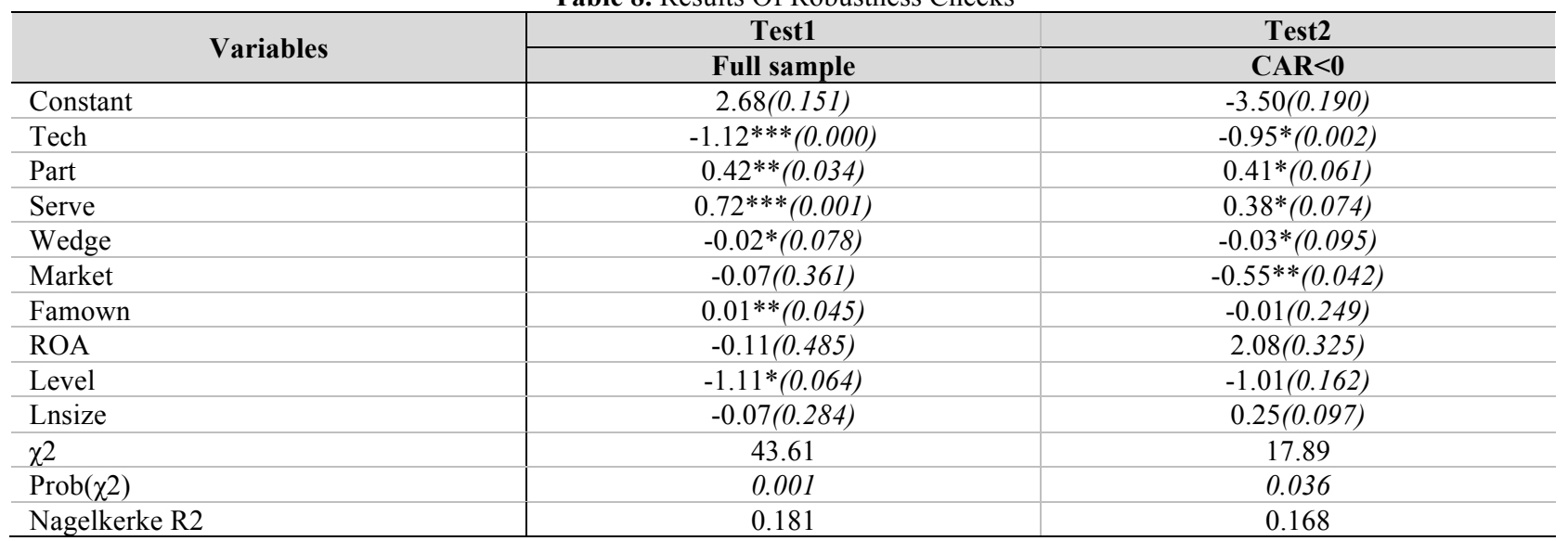

Note: ${ }^{*} p<0.10,{ }^{* *} p<0.05,{ }^{* * *} p<0.01$. The italics are the $p$-values. We use $C A R(-5,5)$ to judge whether managers accept market feedback. Test 1 is for full sample. Test 2 is for subsample including $C A R<0$ only.

In Table 8, all the key variables have the excepted sign, which support H2-H4. In test 1, all of the coefficients of Tech, Part, Serve, and Wedge have expected signs, indicating that family firms' industry can affect the information disclosure. Insiders of high-tech family firms hold far more information than the market, leading to the market less informative.

Family members' participation in purchasing strengthens the supervision imposed on managers. Managers under weak supervision may ignore long-term benefit in order to realize personal gains. Namely, managers are not likely to ignore market feedback when they are strongly monitored.

When family members serve as managers, they know more about the decision. The information asymmetry is less severe between controllers and managers while more severe between controllers and outsiders. For example, family firms may need much fund to finance a project which may take a very long time to make profits. As Kahneman and Tversky (1979) posit, outsiders tend to overweight firms' recent performance at the expense of long-term performance. As insiders, managers know more about the projects than the market, resulting in that managers tend to ignore market feedback and choose to complete the previously announced plan.

Large separation of control rights from ownership can induce serious agency problems. Managers may abuse their power to pursue personal gains, such as more spare time (adjusting the plan may take a long time) and steep discounts for passive investors to acquire lax supervision. Wholly speaking, the results are consistent with our empirical conclusions.

\section{CONCLUSIONS}

Apart from redistributing resources among traders in the secondary market, capital market can also generate information that guides managers' decisions. Market feedback to announcements of the relevant decisions is one of the valuable sources of information to managers. They can observe market feedback to get a better understanding of whether their decisions are value-increasing or value-reducing. Consequently, many studies focus on how managers use market feedback to guide their investment decisions, with very few concerning the relation between market feedback and financing decisions. However, agency problems between shareholders and managers may blind controllers to trust managers, leaving high possibility for managers to pursue personal gains. Thus they may ignore market feedback. Furthermore, whether managers in family firms act as agents or stewards have received perennial concern. Therefore, this study adds to the literature by examining whether managers in family firms accept market feedback in private placement and further explores whether agency problems affect managers' attitude towards market feedback.

We find that managers in family firms generally use market feedback as an input in final decision-making. It is affected by three factors: managers' private information, the supervision imposed on managers, and the corporate 
governance structure. When managers' information is less than that of the market, when managers are strongly monitored, and when managers are more closely aligned with firms, they tend to listen to the market.

Our work has several implications for future research and managerial practice. As for future research, scholars have found that information leakage exists in private placement. Thus, future studies may take it into consideration. As for managerial practice, first, information asymmetry can influence managers' attitude towards market feedback. Insufficient information disclosure brings difficulty to market to evaluate firm value, causing stock prices to fall. Hence, information transparency of private placement should be improved, especially for high-tech firms. Second, family should enhance the supervision on managers and improve managers' alignment with firms to prevent them from pursuing personal gains through private placement or other ways. Third, mechanism of rewards and punishments should be established in family firms. Under this mechanism, in the long run, competent managers should benefit from good decisions and can quantify the benefits. Conversely, managers who fail to listen to the market will bear the costs at their own peril.

\section{ACKNOWLEDGEMENTS}

This study is funded by the National Science Foundation of China [no.71202043] and Social Sciences Research Project of Ministry of Education [no.14XJC790001].

\section{AUTHOR INFORMATION}

Weiwei Gao is a Ph.D. candidate of accounting in the School of Management at Xi'an Jiaotong University. Her main research interests include corporate governance and corporate finance. Mailing address: Mailbox 1851, No. 28, Xianning West Road, Xi'an, Shaanxi, 710049, China. E-mail: gwwsmile_0913@126.com (Corresponding author). Tel: +8613474027988 .

Dr. Wanli Li is a professor of accounting in the School of Management at Xi' an Jiaotong University and the School of Accounting at Shanghai University of International Business and Economics. Her main research interests include accounting restatements, earnings management, corporate governance, and political connections. E-mail: 1wlxjtu@126.com.

Wei Sun is a professor of Investment and Finance in the School of Management at Xi'an Jiaotong University. His research interests include investment, finance, and merger and acquisition. E-mail: sunwei@mail.xjtu.edu.cn.

\section{REFERENCES}

Agarwal, S, Liu, C., \& Rhee, S.G. (2008). Investor demand for IPOs and aftermarket performance: evidence from the Hong Kong stock market. Journal of International Financial Markets, Institutions and Money, 18(2), 176-190.

Aktas, N., de Bodt, E., \& Roll, R. (2009). Learning, hubris and corporate serial acquisitions. Journal of Corporate Finance, 15(5), 543-561.

Aktas, N., de Bodt, E., \& Roll, R. (2011). Serial acquirer bidding: an empirical test of the learning hypothesis. Journal of Corporate Finance, 17(1), 18-32.

Anderson, R.C. \& Reeb, D.M. (2003). Founding-family ownership and firm performance: evidence from the S\&P 500. Journal of Finance, 58(3), 1301-1327.

Asquith, P. \& Mullins, D.W. (1986). Equity issues and offering dilution. Journal of Financial Economics, 15, 61-89.

Barclay, M.J., Holderness, C.G., \& Sheehan, D.P. (2007). Private placements and managerial entrenchment. Journal of Corporate Finance, 13, 461-484.

Blanchard, O., Rhee, C., \& Summers, L. (1993). The stock market, profit, and investment. Quarterly Journal of Economics, $108(1), 115-136$.

Berger, A.N. \& Udell, G.F. (2002). Small business credit availability and relationship lending: the importance of bank organizational structure. Economic Journal, 112, 32-53.

Bubolz, M.M. (2001). Family as source, user, and builder of social capital. Journal of Socio-Economics, 30(2), $129-131$.

Chakraborty, A. \& Hu, C.X., 2006. Lending relationships in line-of-credit and nonline-of-credit loans: evidence from collateral use in small business. Journal of Financial Intermediation, 15(1), 86-107.

Chemmanur, T.J. \& Fulghieri, P. (1999). A theory of the going-public decision. Review of Financial Studies, 12(2), $249-279$. 
Chen, S., Ho, K.W., Lee, C., \& Yeo, G. (2002). Wealth effects of private equity placements: evidence from Singapore. Financial Review, 37(2), 165-183.

Chrisman, J.J., Chua, J.H., Kellermanns, F.W., \& Chang, E.P.C. (2007). Are family managers agents or stewards? An exploratory study in privately held family firms. Journal of Business Research, 60(10), 1030-1038.

Cronqvist, H. \& Nilsson, M. (2005). The choice between rights offerings and private equity placements. Journal of Financial Economics, 78(2), 375-407.

Coleman, S. \& Carsky, M. (1999). Sources of capital for small family-owned businesses: evidence from the national survey of small business finances. Family Business Review, 12(1), 73-85.

Corbetta, G. \& Salvato, C. (2004). Self-serving or self-actualizing? Models of man and agency costs in different types of family firms: a commentary on "Comparing the agency costs of family and non-family firms: conceptual issues and exploratory evidence". Entrepreneurship Theory and Practice, 28(4), 355-362

DeAngelo, H. \& DeAngelo, L. (2000). Controlling stockholders and the disciplinary role of corporate payout policy: a study of the Times Mirror Company. Journal of Financial Economics, 56(2), 153-207.

Dye, R.A. \& Sridhar, S.S. (2002). Resource allocation effects of price reactions to disclosures. Contemporary Accounting Research, 19(3), 385-410.

Fama, E.F. \& Jensen, M.C. (1983). Separation of ownership and control. Journal of Law and Economics, 26(2), $301-325$.

Giammarino, R., Heinkel, R., Hollifield, B., \& Li, K. (2004). Corporate decisions, information and prices: do managers move prices or do prices move managers? Financial Economics, 33(1), 83-110.

Hertzel, M., Lemmon, M., Linck, J.S., \& Rees, L. (2002). Long-run performance following private placements of equity. Journal of Finance, 57(6), 2595-2617.

Hertzel, M. \& Smith, R.L. (1993). Market discounts and shareholder gains for placing equity privately. Journal of Finance, 48(2), 459-485.

Jennings, R.H. \& Mazzeo, M.A. (1991). Stock price movements around acquisition announcements and management's response. Journal of Business, 64(2), 139-163.

Jensen, M.C., \& Meckling, W.H. (1976). Theory of the firm: managerial behavior, agency costs and ownership structure. Journal of Financial Economics, 3(4), 305-360.

Kahneman, D. \& Tversky, A. (1979). Prospect theory: an analysis of decision under risk. Econometrica, 47(2), $263-292$.

Kau, J.B., Linck, J.S., \& Rubin, P.H. (2008). Do managers listen to the market? Journal of Corporate Finance, 14(4), $347-362$.

La Porta, R., Lopez-de-Silanes, F., \& Shleifer, A. (1999). Corporate ownership around the world. Journal of Finance, 54(2), 471517.

Li, W., Gao, W., \& Sun, W. (2015). Do managers in Chinese family firms learn from the market? evidence from Chinese private placement. Journal of Applied Business Research, 31(2), 471-488.

Luo, Y. (2005). Do insiders learn from outsiders? Evidence from mergers and acquisitions. Journal of Finance, 60(4), 19511982.

Mauer, D.C. \& Senbet, L.W. (1992). The effect of the secondary market on the pricing of initial public offerings: theory and evidence. Journal of Financial and Quantitative Analysis, 27(1), 55-79.

Mikkelson, W.H. \& Partch, M.M. (1986). Valuation effects of security offerings and the issuance process. Journal of Financial Economics, 15(1-2), 31-60.

Miller, D. \& Le Breton-Miller, I. (2006). Family governance and firm performance: agency, stewardship, and capabilities. Family Business Review, 19(1), 73-87.

Morck, R. \& Yeung, B. (2003). Agency problems in large family business groups. Entrepreneurship Theory and Practice, 27(4), 367-382.

Roll, R. (1986). The hubris hypothesis of corporate takeovers. Journal of Business, 59(2), 197-216.

Stephens, C.P. \& Weisbach, M.S. (1998). Actual share reacquisitions in open-market repurchase programs. Journal of Finance, 53(1), 313-333.

Tan, R.S.K., Chng, P.L., \& Tong, Y.H. (2002). Private placements and rights issues in Singapore. Pacific-Basin Finance Journal, $10(1), 29-54$.

Uchida, H., Udell, G.F., \& Yamori, N. (2012). Loan officers and relationship lending to SMEs. Journal of Financial Intermediation, 21(1), 97-122.

Verrecchia, R.E. (1983). Discretionary disclosure. Journal of Accounting and Economics, 5, 179-194.

Villalonga, B. \& Amit, R. (2006). How do family ownership, control and management affect firm value? Journal of Financial Economics, 80(2), 385-417.

Wagenhofer, A. (1990). Voluntary disclosure with a strategic opponent. Journal of Accounting and Economics, 12(4), $341-363$.

Wruck, K.H. (1989). Equity ownership concentration and firm value: evidence from private equity financings. Journal of Financial Economics, 23(1), 3-28.

Wu, Z., Chua, J.H., \& Chrisman, J.J. (2007). Effects of family ownership and management on small business equity financing. Journal of Business Venturing, 22(6), 875-895.

Wu, Y. (2004). The choice of equity-selling mechanisms. Journal of Financial Economics, 74(1), 93-119. 